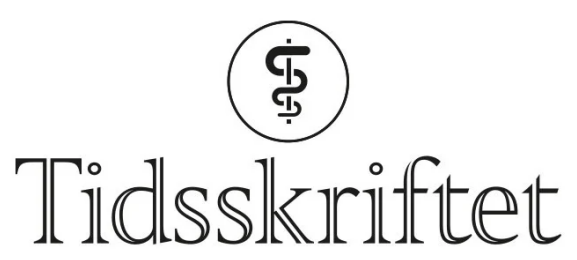

DEN NORSKE LEGEFORENING

\title{
Hvor dødelig er covid-19?
}

\section{LEDER}

\section{HÅON IHLE-HANSEN}

haaihl@vestreviken.no

Håkon Ihle-Hansen er konstituert overlege ved Medisinsk avdeling og seniorforsker ved Forskningsavdelingen ved Vestre Viken, Bærum sykehus.

Forfatteren har fylt ut ICMJE-skjemaet og oppgir ingen interessekonflikter.

\section{Dødeligheten av covid-19 er ikke konstant. Den vil variere over tid og påvirkes av flere ytre faktorer.}

Vi opplever bølge nummer to av covid-19 (1). Mye tyder på at den vil opptre annerledes enn den første, med en annen intensitet, lengde og dødelighet.

Norge sto seg godt gjennom de krevende vårmånedene i 2020. Sammenliknet med andre nasjoner har vi hatt et lavt smittetrykk med få påviste tilfeller og få dødsfall. Gulseth og medarbeidere presenterer nå i Tidsskriftet en oversikt over dødsfall etter påvist covid-19 i Norge (2). Forfatterne har brukt helseregisterdata og redegjør for antall dødsfall og dødeligheten av pandemien i Norge frem til utgangen av mai måned. Det ble numerisk og prosentvis observert flest dødsfall $i$ aldersgruppen 80 år og eldre. Om lag halvparten av de som døde, hadde vært innlagt på sykehus i sykdomsforløpet.

At covid-19 er farlig, er godt dokumentert. Sykdommen har anslagsvis tre ganger høyere dødelighet enn vanlig sesonginfluensa (3). Med tilnærmet fravær av immunitet i befolkningen og et virus som smitter lett, kan antallet dødsfall fort stige, slik vi i høst har sett i deler av Europa og Amerika.

Tross anslaget over er det fortsatt omstridt hvor dødelig viruset faktisk er. Hvordan man definerer covid-19-dødsfall, hvordan man definerer dødelighet, hvilken befolkningsgruppe som er infisert, og hvor mange som testes, påvirker beregningene. Finner man en signifikant økning i antall dødsfall i et år med pandemi sammenliknet med samme periode foregående år, kan man anta at pandemien har ført til en overdødelighet. Med denne metoden korrigeres det for eventuell reduksjon i antall dødsfall av andre årsaker, som direkte eller indirekte kan påvirkes av en pandemi. I Italia, særlig i Lombardia-regionen, har man sett en økt totaldødelighet sammenliknet med foregående år (4), men dette har heldigvis ikke vært tilfellet i Norge. I Norge har vi derimot sett et fall i registrerte dødsfall av hjerte- og karsykdommer og lungesykdommer under den første fasen av pandemien (5). Årsaken til denne endringen er usikker, men det er mulig at endret adferd som følge av pandemien og en derav følgende nedgang i smittsomme sykdommer har spilt en rolle (므). 
I dagspressen blandes tidvis termene mortalitet og letalitet. Mortalitet er andelen av befolkningen som dør av en sykdom i en definert tidsperiode, som regel uttrykt som antall døde per 10 ooo eller 100 ooo innbyggere. Letalitet (case fatality rate) forteller hvor mange av de som har fått påvist sykdom, som dør. Mortalitetsraten påvirkes av forekomsten av sykdommen i befolkningen, mens letaliteten påvirkes av antallet med påvist sykdom. Antallet med påvist smitte avhenger igjen blant annet av teststrategi og hvor mange som testes. Så langt i pandemien har vi sett flere endringer i både teststrategi og testkapasitet. Vi tester i dag langt flere enn det vi hadde mulighet til i pandemiens første fase. Dette medfører at flere enn tidligere får påvist sykdom ( $\varnothing$ kende nevner i brøken), med et tilsvarende fall i letalitetsrate.

\section{«Etter all sannsynlighet er den reelle dødeligheten av covid-19 $i$ Norge}

langt lavere enn $2,9 \%$

Gulseth og medarbeidere rapporterer om en letalitet på 2,9\% i Norge i den første fasen av pandemien. Resultatet må ses i lys av hvem som ble rammet av covid-19, og antall gjennomførte tester i perioden. Etter all sannsynlighet er den reelle dødeligheten av covid19 i Norge langt lavere enn 2,9\%. I enkelte land har man gjennomført serologiske studier for å anslå det totale antallet med gjennomgått covid-19-infeksjon i befolkningen (7.). Når man gjennomfører letalitetsberegninger basert på total antall smittede istedenfor påvist smittede, synker letalitetentil i underkant av o,8 \%, også i land som har vært hardt rammet av pandemien $(\underline{8})$.

Dødeligheten påvirkes også av populasjonen som rammes. Gulseth og medarbeideres studie viser i likhet med studier fra andre land at letaliteten av covid-19 er aldersavhengig, med få registrerte dødsfall i aldersgruppen 60 år og yngre. I den første fasen av utbruddet var det i hovedsak godt voksne og eldre som ble infisert. Barn, unge og unge voksne var underrepresentert blant de med påvist smitte. Det ble derfor innledningsvis antydet at viruset smittet mindre blant unge, men dette er senere avkreftet. I løpet av sommermånedene og tidlig høst har vi igjen sett en økende smittetrend i befolkningen, men denne gangen har de unge vært overrepresentert (1). Dette har medført færre med alvorlig sykdom blant de med påvist smitte, og dermed færre sykehusinnleggelser og lavere dødsrate.

Covid-19 bør fortsatt betraktes som en farlig sykdom, med høy dødelighet, spesielt blant de eldste i befolkningen og de som utvikler et mer alvorlig sykdomsforløp med behov for sykehusinnleggelse. Det viktigste vi som enkeltmennesker og samfunn kan gjøre, er å holde smitten nede.

\section{LITTERATUR}

1. Folkehelseinstituttet. Ukerapport - uke 44.

https://www.fhi.no/contentassets/8a971e7boa3c4ao6bdbf381ab52e6157/vedlegg/andre-halvar2020/2020.11.04-ukerapport-uke-44-covid-19.pdf Lest 12.11.2020.

2. Gulseth HL, Helland E, Johannesen KI et al. Dødsfall etter påvist sars-CoV-2 i Norge. Tidsskr Nor Legeforen 2020; 140. doi: 10.4045/tidsskr.20.0693. [CrossRef]

3. Falnes J. FHI: Coronasmitte tre ganger så dødelig som influensa. VG 9.10.2020. https://www.vg.no/nyheter/innenriks/i/Aldp75/fhi-coronasmitte-tre-ganger-saa-doedelig-sominfluensa Lest 5.11.2020.

4. Alicandro G, Remuzzi G, La Vecchia C. Italy's first wave of the COVID-19 pandemic has ended: no excess mortality in May, 2020. Lancet 2020; 396: e27-8. [PubMed][CrossRef]

5. Folkehelseinstituttet. Lavere dødelighet i Norge for noen sykdommer under pandemien. https://www.fhi.no/nyheter/2020/lavere-dodelighet-i-norge-for-noen-sykdommer-under-pandemien/ Lest 12.11.2020. 
6. Folkehelseinstituttet. MSIS-rapport for august viser fortsatt nedgang i rapporterte smittsomme sykdommer. https://www.fhi.no/nyheter/2020/aktuelt-fra-msis/ Lest 16.11.2020.

7. Pollán M, Pérez-Gómez B, Pastor-Barriuso R et al. Prevalence of SARS-CoV-2 in Spain (ENE-COVID): a nationwide, population-based seroepidemiological study. Lancet 2020;396: 535-44. [PubMed] [CrossRef]

8. O'Driscoll M, Dos Santos GR, Wang L et al. Age-specific mortality and immunity patterns of SARSCoV-2. Nature 2020; 587. doi: 10.1038/s41586-020-2918-o. [PubMed][CrossRef]

Publisert: 14. desember 2020. Tidsskr Nor Legeforen. DOI: 10.4045/tidsskr.20.o9o6 (C) Tidsskrift for Den norske legeforening 2023. Lastet ned fra tidsskriftet.no 26. april 2023. 